\section{Top-Stop Nipper Reduces Leader Growth in Fraser Fir Christmas Trees}

\author{
M. Elizabeth Rutledge ${ }^{1,2}$, John Frampton ${ }^{1,3}$, L. Eric Hinesley ${ }^{1,4,6}$, \\ and Gary Blank ${ }^{1,5}$
}

Additional index words. Abies fraseri, shearing, consumer preference, crown density

\begin{abstract}
Summary. The Top-Stop Nipper (TSN), a four-bladed, hand-held tool used to reduce leader growth in Christmas trees, was evaluated on fraser fir (Abies fraseri). The TSN placed incisions (nips) on the previous year's leader to reduce the amount of photosynthate transported to the developing leader. Treatments consisted of a control (zero nips), and one, two, three, or four nips at each of three stages of leader elongation (pre-budbreak, $2-3 \mathrm{~cm}$, and 6-9 cm). The TSN significantly reduced leader elongation. The percentage of leaders that were within the target range of 8 to 14 inches $(20.3-35.6 \mathrm{~cm}$ ) increased from $18 \%$ for the control (no nips) to $46 \%$ with four nips. The TSN, when combined with traditional knife shearing or growth regulator treatments, might offer a method to produce dense trees with minimal shearing or to leave longer leaders to produce a more open "European-style" tree during a shorter rotation time.
\end{abstract}

$\mathrm{I}$ $\mathrm{n}$ recent years, the fraser fir has gained popularity as a Christmas tree within the United States because of its conical shape, dark green foliage, pleasant aroma, and excellent needle retention (Hinesley et al., 1995). Fraser fir is sheared once annually to produce Christmas trees with dense crowns. Traditional shearing removes the apical bud cluster from the leader and from most large branches while also removing many lateral buds on the distal end of the shoots.

Fir species (Abies spp.) can be sheared almost anytime during the year, but July to August is optimum

This research was funded by the North Carolina Agricultural Research Service (NCARS), Raleigh, via the Christmas Tree Genetics Program.

We thank Avery County Extension Director, Jerry Moody, and Avery County IPM Technician, Doug Hundley, for guidance and support. We also thank Avery County Christmas tree growers, Herbie and Dan Johnson, Boyd McCloud, and Jack Wiseman, for allowing use of their Christmas trees. We thank Sandy Donaghy, NCSU Department of Statistics, for assistance with SAS programming. The use of trade names does not imply endorsement by the NCARS of products named nor criticism of similar ones not mentioned. This paper is from the senior author's MS thesis.

${ }^{1}$ Department of Forestry and Environmental Resources North Carolina State University Raleigh, NC 27695-8008

${ }^{2}$ Graduate student.

${ }^{3}$ Professor

${ }^{4}$ Professor, Department of Horticultural Science. E-mail: eric_hinesley@ncsu.edu.

${ }^{5}$ Associate Professor.

${ }^{6}$ Corresponding author. E-mail: eric_hinesley@ncsu.edu.
(Brown and Heiligmann, 2002; Douglass, 1983; Hinesley and Derby, $2004 a, 2004 b$ ). Leaders of fraser fir normally are shortened to 20 to 50 $\mathrm{cm}$ (traditional system) each year, often less than half of full length. The sheared length varies according to tree age, its potential for growth, and customer preferences (Hinesley et al., 1998). Shearing to a longer average leader length (accelerated system) would result in a tree with a more open, natural appearance.

To remain competitive, Christmas tree growers must minimize production costs while accounting for consumer preferences. In response to preference for higher density trees, the practice of shearing began during the 1940s and 1950s (Chastagner and Benson, 2000). Shape is the most important factor affecting Christmas tree selection, followed by needle retention, species, and price (North Carolina Department of Agriculture and Consumer Services, 2002). American consumers prefer dense trees, which require annual shearing, whereas Europeans like a more natural appearance, which requires little to no shearing (Frampton and McKinley, 1999). The European style is more open with layered internodal branching and more uniform whorls (Chastagner and Benson, 2000). European trees tend to have gaps between the whorls to accommodate more traditional decorations such as candles. American and European consumers both prefer an adequate number of internodal branches on which to hang ornaments. To accommodate smaller rooms, many Europeans also prefer slower grown Christmas trees with smaller crown diameters and low to medium density (Frampton and McKinley, 1999).

The Top-Stop Nipper (TSN; Lars Geil, Ry, Denmark) is a plier-like tool with two unevenly spaced $(\approx 2$ $\mathrm{cm}$ apart) blades on either side of the crimping end, each with a half circle cut out (Fig. IA). It was developed in Denmark to reduce terminal leader growth by placing transverse incisions (perpendicular to the long axis) on the previous year's leader (Fig. 1B). The incisions partly sever the phloem and possibly part of the cambium, but when used properly, they stop at the xylem. The incisions reduce leader growth by disrupting the flow of photosynthate to the developing leader. Some photosynthate is used for wound healing at the incisions. In Europe, the TSN reduced leader growth by $25 \%$ in nordmann fir (Abies nordmanniana; Owen et al., 2004). The proportion of European growers who use the TSN is unknown, but the manufacturer has sold about 200 units annually during the last 2 or 3 years ( $\mathrm{L}$. Geil, pers. comm.).

Traditional shearing involves hand pruning the leader and top whorl, and pruning the sides of the tree with a knife or gasoline-powered trimmer. Advantages of the TSN, compared with traditional shearing, include regulation of the top, no chemical applications, one-time use, low cost, ease of use, and it requires little time per tree. In addition, leaving the terminal and subterminal buds intact maintains the mechanism of correlative inhibition among leaders and lower-order shoots (Kozlowski

\begin{tabular}{llll}
\hline $\begin{array}{l}\text { Units } \\
\begin{array}{l}\text { To convert U.S. to SI, } \\
\text { multiply by }\end{array}\end{array}$ & U.S. unit & SI unit & $\begin{array}{l}\text { To convert SI to U.S., } \\
\text { multiply by }\end{array}$ \\
\hline 0.3048 & $\mathrm{ft}$ & $\mathrm{m}$ & 3.2808 \\
2.54 & inch(es) & $\mathrm{cm}$ & 0.3937
\end{tabular}





Fig. 1. (A) Jaws and cutter blades on the Top-Stop Nipper (TSN). (B) Application of cuts to a leader of fraser fir using the TSN. (C) Leader elongation of a nontreated control tree. (D) Leader elongation of a tree that received four nips with the TSN.

et al., 1973; Little, 1970), thus enabling lateral branches to form more naturally as in a nonsheared tree. This produces a full, uniform tree without having to shear the tops annually. The objective of this research was to determine the effectiveness of the TSN at reducing leader growth of Fraser fir Christmas trees.

\section{Materials and methods}

The experiment was conducted in three commercial fraser fir Christmas tree plantations $(3410-4000 \mathrm{ft}$ elevation; average lat. $36.1^{\circ} \mathrm{N}$, average long. $81.8^{\circ} \mathrm{W}$ ) in Avery County in western North Carolina during 2005.
Stands were typical of Christmas tree plantations in that region. A total of 900 trees (height $\approx 4-5 \mathrm{ft}$ ) were used. Most trees had been in the field for 5 years and were likely 5 years from seed when planted. Standard cultural practices included one mechanical shearing annually, usually in late summer. Trees were not sheared during the experiment. Trees were excluded that were too short, too tall, diseased, or insect damaged.

Before treatment, total height through 2003 and 2004 was measured on each tree. Sheared leader length for 2004 was calculated by difference. On the uppermost bud on the 2004 leader, two cross-sectional diameters (top to bottom and side to side) were measured with a digital caliper. The two numbers were averaged and multiplied by bud length to calculate total bud volume. Before bud swelling, leader diameter for 2005 was measured $4 \mathrm{~cm}$ above its insert on the stem.

The experimental design was a randomized complete block with $4 \times$ 3 factorial plus control replicated at three sites. There were 20 blocks per site. Owing to the uniformity of the sites, blocks were about square. Each block had 15 trees (three controls plus one tree for each treatment involving one, two, three, or four nips at three stages of leader elongation: pre-budbreak, 2 to $3 \mathrm{~cm}$, and 6 to $9 \mathrm{~cm}$. Each nip consisted of the insertion of four blades into the bark, stopping at the xylem (Fig. 1B). When using multiple nips, the tool was rotated $90^{\circ}$ before applying each additional nip. Nips were positioned to reduce damage to lateral buds and shoots. Pre-budbreak treatments were applied on 30 Apr. The remaining treatments were applied to each tree as the new leader reached the appropriate stage of elongation.

On site 2, weekly measurements were recorded for every tree over 7 weeks, beginning 26 June. Final measurements were taken at all sites after 9 weeks. Means were plotted for site 2 after $1,2,3,4,5,6,7$, and 9 weeks, but only for week 9 on the other two sites. Data were analyzed using GLM and REG procedures (SAS Institute, Cary, NC). Regressions were developed to describe the relationship between leader length and time for the control trees and trees treated with three nips at site 2 . A combined analysis of variance (Table 1) for leader length was carried out to test sources of variation for sites, time of treatment, number of nips, and interactions. Components of the experimental error had similar mean squares; therefore, a pooled error term was used for testing treatment effects. A separate analysis also was carried out for each of the three sites (Table 2). One of the $12 \mathrm{df}$ for treatments in each analysis was used in a comparison of "control vs. nipped." In addition, an analysis of covariance was conducted to test the relationship between each covariable (bud volume, leader diameter, leader length 
in 2004, and tree height) and final leader length in 2005.

Within nipping treatments, final leader length was compared with two target ranges for leader length (traditional and accelerated). These ranges refer to the leader length, which is set during shearing. With a traditional system, leaders would be cut to a length of 8 to 14 inches, whereas the accelerated system would leave leaders 12 to 18 inches in length. For each system, percentages were calculated for the number of leaders that were too short, optimum, or too long relative to the ideal target length.

\section{Results and discussion}

In the combined analysis for 9-week data (Table 1), the following

Table 1. Combined analysis of leader length for fraser fir Christmas trees treated with a TSN. ${ }^{\mathrm{z}}$

\begin{tabular}{lrc}
\hline $\begin{array}{l}\text { Source of } \\
\text { variation }^{\text {y }}\end{array}$ & df & $\begin{array}{l}\text { Leader } \\
\text { length }\end{array}$ \\
\hline $\begin{array}{l}\text { Treatments } \\
\text { Site }=\mathrm{S}\end{array}$ & 2 & $* *$ \\
Block $(\mathrm{S})$ & 57 & - \\
Control $=\mathrm{C}$ & 1 & $* *$ \\
Time $=\mathrm{T}$ & 2 & $* *$ \\
$\mathrm{Nips}=\mathrm{N}$ & 3 & $* *$ \\
$\mathrm{~T} \times \mathrm{N}$ & 6 & $\mathrm{NS}$ \\
$\mathrm{S} \times \mathrm{T}$ & 4 & $* *$ \\
$\mathrm{~S} \times \mathrm{N}$ & 6 & $\mathrm{NS}$ \\
$\mathrm{S} \times \mathrm{T} \times \mathrm{N}$ & 12 & $\mathrm{NS}$ \\
$\mathrm{S} \times \mathrm{C}$ & 2 & $* *$ \\
Error & 793 & - \\
$\mathrm{R}^{2}=0.5 \mathrm{l}$ & & \\
\hline
\end{tabular}

${ }^{\mathrm{z}}$ The TSN is a plier-like tool with two unevenly spaced blades [ $2 \mathrm{~cm}(0.8$ inch $)$ apart] on each jaw, each with a half-circle cut out.

y There were three Christmas tree plantation sites $(S)$, 20 blocks per site $[\operatorname{Block}(S)]$, three treatment dates $(\mathrm{T})$, and four nipping treatments $(\mathrm{N})$.

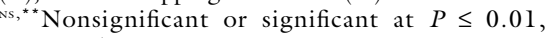
respectively.

Table 2. Combined analysis of leader length for fraser fir Christmas trees treated with a TSN. ${ }^{\mathrm{z}}$

\begin{tabular}{|c|c|c|c|c|}
\hline Source of variation ${ }^{y}$ & df & Site 1 & Site 2 & Site 3 \\
\hline Blocks & 19 & - & - & - \\
\hline Treatments & 12 & & & \\
\hline Time & 2 & ** & NS & NS \\
\hline Nips & 3 & ** & ** & ** \\
\hline Time $\times$ Nips & 6 & NS & NS & NS \\
\hline Control vs. nipped & 1 & ** & ** & ** \\
\hline Error & & 258 & 268 & 267 \\
\hline$R^{2}$ & & 0.36 & 0.27 & 0.28 \\
\hline
\end{tabular}

sources were significant: site $(S)$, date of treatment $(\mathrm{T})$, number of nips $(\mathrm{N})$, and the interaction of site $\times$ time of application $(S \times T)$. Nipping treatments were significant on all three individual sites, whereas date of treatment was significant only at site 1 (Table 2). In the analysis of covariance, leader diameter in 2004 $(r=-0.29, P \leq 0.05)$ and bud volume in $2004(r=0.47, P \leq 0.05)$ were more strongly related to leader length in 2005 compared with tree height in $2004(r=0.14, P \leq 0.05)$ and leader length in $2004(r=0.10$, $P \leq 0.05$ ). In the field, it would be easier to use bud length as an indicator of potential leader growth $(r=0.29, P \leq 0.01)$ rather than bud volume $(r=0.47, P \leq 0.01)$. The correlation of bud length to bud volume was 0.83 .

Leader elongation was greatest in controls (Fig. 1C vs. 1D), and decreased as the severity of wounding increased up to three nips (Fig. 2A). Applying a fourth nip had little additional effect. The pattern of leader elongation was similar for all nip treatments (Fig. 2A). Site 1, where leader growth was most vigorous, was also the only site where timing of nip treatments was significant (Table 2); applying the nips at budbreak caused less reduction of leader growth compared with treatment at later stages of development (Fig. 2B). On site 2, nipping treatments yielded similar results for all application dates (Fig. 2B); the pattern was similar on site 3 .

Bud density (number of buds per centimeter of leader length) tended to increase with the number of nips (data not presented). This resulted because the total number of buds did not change even though leader length decreased in response to nipping.

When all levels of nips over the three sites were averaged, $35 \%$ of the leaders were in the target range $(20.3-35.6 \mathrm{~cm})$ for the traditional shearing regime, whereas $39 \%$ were in the target range $(30.5-45.7 \mathrm{~cm})$ for the "accelerated" regime (Fig. 3). For the traditional regime, the percentage of leaders that were within the target range increased from $18 \%$ for the control (no nips) to $46 \%$ with four nips (Fig. 3A). Even though almost half of the leaders were within the target range for three or four nips, $38 \%$ to $45 \%$ of the leaders were still too long (Fig. 3A). For the accelerated regime, three to four nips yielded $40 \%$ to $42 \%$ of leaders in the target range, and only $15 \%$ to $20 \%$ were too long (Fig. 3B).

The TSN effectively reduced leader growth in fraser fir Christmas trees. In a similar experiment in the Pacific northwestern United States, the TSN reduced leader growth of noble fir (Abies procera) and nordmann fir by $25 \%$ to $50 \%$, depending on the species and individual tree (Fletcher et al., 2005). For nontreated noble fir, about $22 \%$ of trees produced leaders in the target range, while nipping increased the yield to 46\% (Landgren and Fletcher, 2006). A study with the TSN in western North Carolina in 2004 showed that four nips reduced leader growth of Fraser fir by $32 \%$ without reducing bud counts on the leaders (Owen et al., 2004).

In conifers, formation of the terminal leader is a 2 -year process (Powell, 1982). The first year consists of formation of bud primordia, which determines the amount of leader elongation during the second year. Favorable environmental conditions during this period produce more shoot growth during the second year (Kozlowski, 1962). Bud size is a good indicator of subsequent shoot growth (Kozlowski et al., 1973; Little, 1970). Fraser fir is excurrent; therefore, the new leader displays dominance (apical control) over the laterals, which allows for greater allocation of photosynthate to the developing leader. For a time after budbreak, the leader is a carbohydrate sink within the tree. This period of growth is determined by climate, species, and genotype 


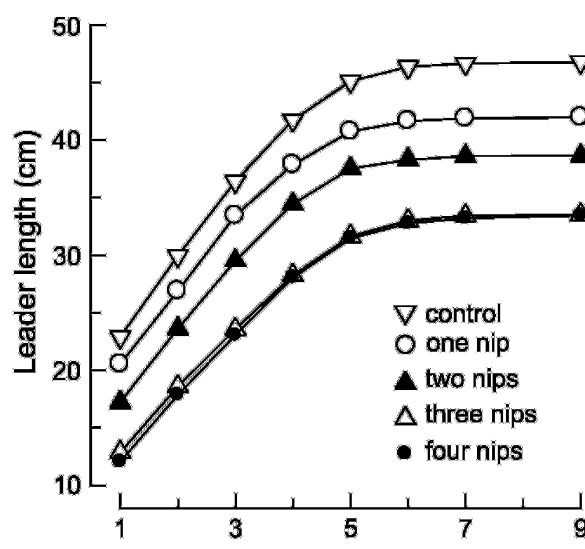

A

Week

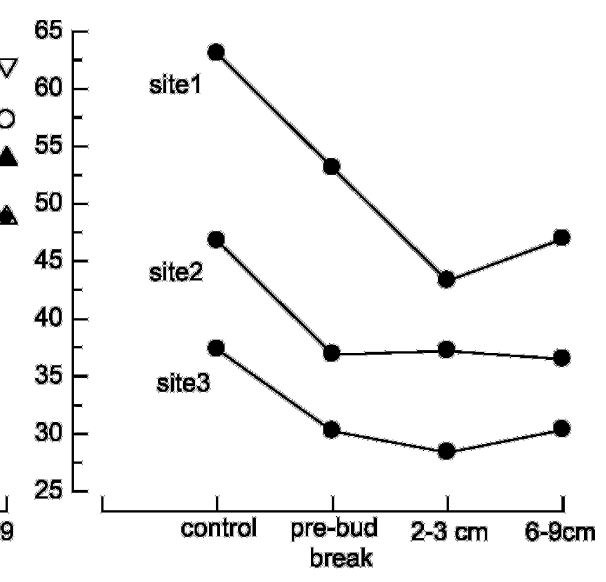

B

Time of treatment

Fig. 2. (A) Average leader length (LL) for Top-Stop Nipper (TSN) treatments in a fraser fir Christmas tree plantation (Site 2). Measurements were taken at weeks $1,2,3,4,5,6,7$, and 9. Plotted lines are for means; $n=60$ for each mean. Model for three nips: $\mathrm{LL}_{(3 \mathrm{nips})}=11.8+11.75 \times \ln ($ week $), R^{2}=0.98$. Model for control treatment: $\mathrm{LL}_{(\text {cont })}=21.9+13.82 \times \ln ($ week $), R^{2}=0.99,(B)$ interaction between site and application time for final LL. Means are shown for individual sites and times of application. Data points: $n=80$ for nip treatments; $n=60$ for controls. SE for nip treatments $=\mathbf{1 . 2 4}$.


Fig. 3. Percentage of fraser fir Christmas trees with final leader length (LL) classified as short, target, or long for four treatments with a Top-Stop Nipper (TSN) and a nontreated control. (A) Traditional shearing regime: target LL $=8$ to 14 inches $(20.3$ to $35.6 \mathrm{~cm})$. (B) Accelerated shearing regime: $\operatorname{target} L L=12$ to 18 inches $(30.5$ to $45.7 \mathrm{~cm})$. Results are averaged across three sites.

(Luxmoore et al., 1995). Later, the leader becomes self-sufficient with regard to carbohydrate production and finally becomes a carbohydrate source and storage site for other parts of the tree (Luxmoore et al., 1995).

Incisions placed on the previous year's leader by the TSN sever the phloem and most likely damage the vascular cambium as well. This reduces the amount of photosynthate reaching the developing leader during the second year of growth, and a portion of the transported nutrients is also devoted to wound repair. In the present investigation, the degree of reduction in leader length increased divided among the three categories than the traditional regime, increasing the percentage of acceptable trees. Unless the technique can produce a greater percentage of trees with target leader lengths, growers are unlikely to adopt this practice. With current shearing practices, virtually $100 \%$ of trees have leader lengths within the target range. An alternative would be to use the TSN on all trees before or just after budbreak, and later, mechanically shear only those leaders that are longer than the target length. A further refinement - as practiced by some European growers-is to use the TSN on all trees, and shortly thereafter, apply a growth regulator to the longest leaders to further reduce elongation (L. Geil, pers. comm.).

The success of the TSN might be influenced by consumer preference. For a particular species and height class, about half of consumers view full and open trees as similar in value, whereas $13 \%$ are willing to pay a premium price for a more open tree (Helmsing, 2003). However, such information should be interpreted conservatively, because consumer surveys sometimes do not agree with sales figures from growers. Most consumers who prefer a more open tree are women, who are responsible for about $80 \%$ of Christmas tree purchases (Helmsing, 2003). In general, women decorate with more ornaments, which require more space for placement. An open, more-natural tree can hold up to two-thirds more ornaments than a heavily sheared tree (Dishneau, 2004). For trees of a given height, an open tree weighs less than a dense tree, providing several advantages: easier harvesting, lower transportation costs, and ease of handling, especially for women and children.

In summary, the TSN reduced leader growth of fraser fir Christmas trees and might provide an alternative to traditional shearing if combined with traditional mechanical shearing or treatment with a growth regulator. It has the potential to form a more open, "European style" tree with a layered, natural appearance. However, there is so much variation in response among trees and sites that a single treatment is not appropriate for all situations. More nips are required on vigorous trees to achieve the desired target range of leader length. 
Currently, the effect of the TSN on long-term appearance, quality, and marketability of fraser fir Christmas trees is unknown.

\section{Literature cited}

Brown, J.H. and R.B. Heiligmann. 2002. Shearing West Virginia balsam and Fraser fir for Christmas trees. Ohio State Univ. Ext. Bull. Spec. Circ. 188.

Chastagner, G.A. and D.M. Benson. 2000. The Christmas tree: Traditions, production, and diseases. Plant Health Progress. Plant Health Rev. DOI:10.1094.

Dishneau, D. 2004. Grower suggests opening your mind to more open Christmas trees. 28 Mar. 2007. <http://wtop. com $/$ index.php? nid $=25 \&$ pid $=0 \&$ sid $=$ 344346\&page $=1>$.

Douglass, B.S. 1983. Noble fir shearing and fertilizer study. Pacific Northwest Christmas Tree Assn., Christmas Tree Lookout 16(3):30-32, 34, 36, 38, 40.

Fletcher, R., C. Landgren, and M. Bondi. 2005. Control of Abies leader growth in Oregon Christmas trees via chemical and mechanical manipulation. Seventh Int. Christmas Tree Res. Ext. Conf. 2-7 Oct. 2005, Tustin, MI. Program and Abstracts, p. 14-15. Michigan State Univ., East Lansing, MI.
Frampton, J. and C.R. McKinley. 1999 Christmas trees and greenery in Denmark: Production and tree improvement. Amer. Christmas Tree J. 43(2):4-11.

Helmsing, P. 2003. The perfect Christmas tree. Amer. Christmas Tree J. 47 (2):34-35.

Hinesley, L.E. and S.A. Derby. 2004a. Shearing date affects growth and quality of Fraser fir Christmas trees. HortScience 39:1020-1024.

Hinesley, L.E. and S.A. Derby. 2004b. Growth of Fraser fir Christmas trees in response to annual shearing. HortScience 39:1644-1646.

Hinesley, L.E., W.T. Huxster, and C.R. McKinley. 1995. Retail merchandising of North Carolina Fraser fir. North Carolina Coop. Ext. Serv., Raleigh.

Hinesley, L.E., S.L. Warren, and L.K. Snelling. 1998. Effect of uniconazole on shoot growth and budset of containerized Fraser fir. HortScience 33:82-84.

Kozlowski, T.T. 1962. Tree growth. Ronald Press, New York.

Kozlowski, T.T., J.H. Torrie, and P.E. Marshall. 1973. Predictability of shoot length from bud size in Pinus resinosa Ait. Can. J. For. Res. 3:34-38.
Landgren, C. and R. Fletcher. 2006. From Europe to the Pacific Northwest. Amer. Christmas Tree J. 50(2):20-21.

Little, C.H.A. 1970. Apical dominance in long shoots of white pine (Pinus strobus). Can. J. Bot. 48:239-253.

Luxmoore, R.J., R. Oren, D.W. Sheriff, and R.B. Thomas. 1995. Source-sinkstorage relationships in conifers, p. 197198. In: W.K. Smith and T.M. Hinckley (eds.). Resource physiology of conifers: Acquisition, allocation, and utilization. Academic Press, New York.

North Carolina Department of Agriculture and Consumer Services. 2002. Evaluation of the competitive position of the Fraser fir Christmas tree. Div. Mktg., Div. Agr. Stat., North Carolina Dept. Agr. Consumer Affairs, Raleigh.

Owen, J., J. Frampton, J. Moody, and L. Geil. 2004. Top-Stop Nipper terminal growth reduction trials, p. 43. In: J. Sidebottom (ed.). Christmas tree research and extension projects: First annual summary. North Carolina Coop. Ext. Serv., Raleigh.

Powell, G.R. 1982. Shoot and bud development in balsam fir: Implications for pruning of Christmas trees. For. Chron. 58:168-172. 